\title{
Nutrient exposure causes epiphytic changes and coincident declines in two temperate Australian seagrasses
}

\author{
Simon Bryars ${ }^{1, *}$, Greg Collings ${ }^{2}$, David Miller ${ }^{3}$ \\ South Australian Research and Development Institute (Aquatic Sciences), PO Box 120, Henley Beach, South Australia 5022, \\ Australia \\ ${ }^{1}$ Present address: PO Box 67, Verdun, South Australia 5245, Australia \\ ${ }^{2}$ Present address: Birdwood High School, Birdwood, South Australia 5234, Australia
}

${ }^{3}$ Present address: Department of Environment and Natural Resources, GPO Box 1047, Adelaide, South Australia 5001, Australia

\begin{abstract}
We undertook a long-term $(27 \mathrm{mo})$ field experiment to test if a chronic increase in water column nutrients could cause a decline in 2 temperate Australian seagrasses and if this decline could be linked to nutrient-mediated changes in epiphytes. Two seagrasses, Amphibolis antarctica and Posidonia sinuosa, were exposed to minor increases ( 2 to $5 \times)$ in nutrient (N, P) concentrations utilising slow-release fertiliser over a 15 mo period at a shallow ( $2 \mathrm{~m}$ depth), oligotrophic marine site in Gulf St Vincent, South Australia. Fertiliser had a significant detrimental effect on biomass, density, and canopy height in both seagrasses. Moreover, the seagrass biomass reductions coincided with increased epiphyte loads and changes in epiphyte composition. After a 12 mo recovery period, epiphyte loads in the fertiliser treatments had returned to levels comparable to the control, but the fertiliser-treated seagrasses had not recovered. While the precise mechanism of seagrass decline is still unclear, our results have demonstrated that (under certain circumstances) chronic, yet minor, increases in water column nutrient concentrations can cause the slow decline of Amphibolis and Posidonia spp. Furthermore, while future management decisions regarding anthropogenic nutrient discharges into seagrass ecosystems should be assessed on a case-by-case basis, our results and those of other workers investigating large-scale losses of Amphibolis and Posidonia in southern Australia indicate that extreme caution must be applied where these seagrasses occur in shallow, sheltered oligotrophic marine environments.
\end{abstract}

KEY WORDS: Seagrass - Nutrients - Epiphytes - Seagrass decline - Amphibolis antarctica Posidonia sinuosa

Resale or republication not permitted without written consent of the publisher

\section{INTRODUCTION}

Coastal seagrass coverage is continuing to decline worldwide (Walker et al. 2006, Waycott et al. 2009). Eutrophication in the form of increased water column nutrients from anthropogenic inputs has been implicated as one of the major causes (Ralph et al. 2006, Burkholder et al. 2007). Deleterious effects of ele- vated nutrients on seagrasses have been demonstrated or correlated in numerous studies, with various causal mechanisms proposed (for reviews see Walker \& McComb 1992, Hauxwell \& Valiela 2004, Hughes et al. 2004, Ralph et al. 2006, Burkholder et al. 2007). However, eutrophication-related declines in seagrasses have mainly been linked to 2 processes: (1) shading by phytoplankton and (2) overgrowth by 
macroalgae or epiphytes (for review see Burkholder et al. 2007). Nonetheless, other mechanisms are also possible, such as increased herbivore grazing on more heavily epiphytised seagrasses and greater grazing pressure on nutrient-rich fresh leaf material (Romero et al. 2006, Heck \& Valentine 2007). An increase in water column nutrients could also potentially have a direct toxic effect on seagrasses (Burkholder et al. 2007).

Epiphytes are naturally occurring organisms that grow upon plants (as defined by Borowitzka \& Lethbridge 1989, Borowitzka et al. 2006). The ratio of epiphyte biomass to aboveground seagrass biomass (or plant surface area) is often referred to as the epiphyte load. Thus, an increase in epiphyte biomass relative to a stable seagrass biomass results in an increased epiphyte load. Epiphyte load (and composition) is the manifestation of a complex interaction of many factors, including light, temperature, nutrients, grazing pressure, hydrodynamics and propagule supply (Borowitzka \& Lethbridge 1989, Borowitzka et al. 2006). Consequently, seagrass epiphytes are often temporally and spatially variable in the natural environment. Nonetheless, many epiphytic algae are opportunistic species that will thrive under certain environmental conditions (e.g. increases in nutrients, light and temperature), and eutrophication of the water column can cause changes in both epiphyte load and composition (Wear et al. 1999, Cambridge et al. 2007, Prado et al. 2008a). These epiphytes may then have a range of negative effects on the host seagrass (Silberstein et al. 1986, Short et al. 1995). Consequently nutrient-mediated changes in epiphytes have been linked with seagrass declines worldwide (Borowitzka et al. 2006), including large-scale losses in the temperate Australian seagrass genera Amphibolis and Posidonia (e.g. Cambridge et al. 1986, 2007, Silberstein et al. 1986, Neverauskas 1987, Shepherd et al. 1989, Hillman et al. 1991, Walker \& McComb 1992). Many of these Australian examples have linked seagrass loss with a chronic increase in water column nutrients (caused by anthropogenic sources such as industrial outfalls and agricultural run-off) and a change in epiphyte load or composition.

While a large amount of manipulative experimentation has already been conducted on the chronic effects of nutrients and/or grazers on seagrasses and their epiphytes (e.g. Wear et al. 1999, Heck et al. 2000, 2006, Hays 2005, Prado et al. 2008a, Baggett et al. 2010), relatively little comparative work has been undertaken in southern Australia for the 2 dominant genera Amphibolis and Posidonia. In order to further our understanding of past seagrass declines in south- ern Australia, and to better understand links between nutrients, epiphytes and seagrass decline in general, we undertook a long-term field experiment utilising slow-release fertiliser to maintain elevated nutrient levels in the water column surrounding the seagrasses Amphibolis antarctica (Labill.) Sonder et Aschers and Posidonia sinuosa Cambridge and Kuo. We specifically wanted to test: (1) if a chronically elevated nutrient concentration could cause decline in A. antarctica and P. sinuosa, (2) if any observed seagrass decline was coincident with an increased epiphyte load or change in epiphyte composition, and (3) if these 2 seagrasses could recover following the cessation of nutrient exposure. We did not propose to identify the precise mechanism of seagrass decline but rather to provide experimental support for links among nutrient exposure, changes in epiphytes and seagrass decline. Nonetheless, efforts were made to determine possible causes of seagrass decline and thus we also tested if elevated nutrients had an effect on: (1) rates of leaf initiation (in A. antarctica) and leaf elongation (in $P$. sinuosa), (2) photosynthetic efficiency, (3) nutrient accumulation in seagrasses, (4) leaf strength ( $P$. sinuosa only) and (5) grazing gastropod numbers.

\section{MATERIALS AND METHODS}

\section{Study site}

Two contiguous adjoining seagrass meadows, 1 of Amphibolis antarctica and 1 of Posidonia sinuosa, were located in $\sim 2 \mathrm{~m}$ depth, ca. $8 \mathrm{~km}$ south of Port Vincent in Gulf St Vincent, South Australia $\left(34.81^{\circ} \mathrm{S}\right.$, $137.84^{\circ} \mathrm{E}$; Fig. 1). During March 2005 (the Austral autumn), six $1.5 \times 1.5 \mathrm{~m}$ square experimental plots $\left(2.25 \mathrm{~m}^{2}\right.$ per plot), linearly separated by $20 \mathrm{~m}$, were selected in each meadow. Plots were alternately assigned to 1 of 2 treatments: control $(n=3)$ or fertiliser $(n=3)$. The use of alternate rather than random assignment of plots was employed to reduce the possibility of a natural gradient in meadow structure confounding interpretation of the experimental response; ideally we wanted there to be no significant difference between treatments at the beginning of the experiment (cf. Heck et al. 2006, see 'Data analysis').

For each plot, a single steel tent peg was inserted at each corner and in the centre, with $\sim 300 \mathrm{~mm}$ of the peg appearing vertically above the substrate level. A total of 9 nylon mesh bags were then attached to the pegs, with pairs of bags at the corners and a single bag at the centre. Bags contained $454 \mathrm{~g}$ of either 


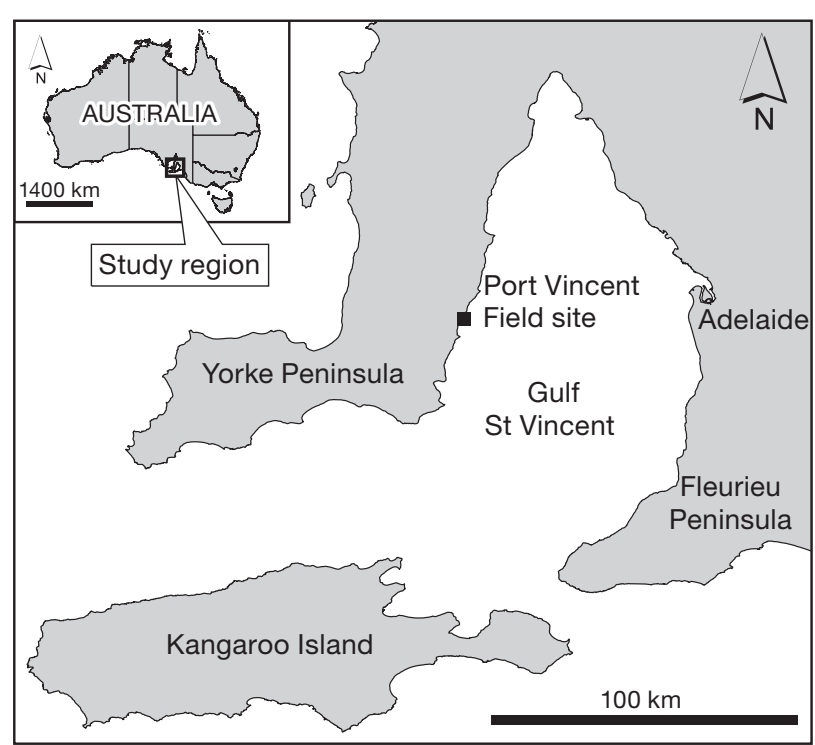

Fig. 1. Location of the field site in western Gulf St Vincent, South Australia, which was used for the nutrient experiment

gravel (procedural 'control plots') or 3 to 4 mo slowrelease Osmocote ${ }^{\circledR}$ fertiliser $(18 \%$ total nitrogen = $7.5 \%$ nitrate $+10.5 \%$ ammonia, $4.3 \%$ total phosphorus) ('fertiliser plots'). A total of $4086 \mathrm{~g}$ of fertiliser was available to each plot. Bags lay just above the sediment surface within the seagrass canopy. Fertiliser bags were replaced approximately monthly over a 12 mo period, whilst the gravel bags were shaken at the same intervals to maintain a similar level of disturbance between control and fertiliser plots. At $12 \mathrm{mo}$, bags were replaced for the last time and the experimental site was left undisturbed for a further 15 mo at which time the experiment was terminated (June 2007). If we assume that the fertiliser bags were exhausted within 3 mo (which is reasonable based upon release rates and laboratory observations-see below), then the experiment had 2 distinct phases: an exposure phase of $\sim 15$ mo and a recovery phase of $\sim 12$ mo.

Slow-release fertiliser is often used in field experiments because it controls the rate of nutrient release (e.g. Wear et al. 1999), thus enabling an extended period of time before the fertiliser needs replacement. The amount of fertiliser we used was based on Wear et al. (1999) and an in-house leaching trial that confirmed nutrients were still available for release from field-deployed bags at $28 \mathrm{~d}$ and from laboratory tank-soaked bags at up to $42 \mathrm{~d}$ post-immersion. Mean release rates from $454 \mathrm{~g}$ bags that had been aged in flow-through tanks for 1, 7, 14, 21, 28, 35 and $42 \mathrm{~d}$ were $200 \mathrm{mg} \mathrm{h}^{-1}$ for each of ammonia as $\mathrm{N}$ or ammoniacal nitrogen (ammonia + ammonium) and oxidised nitrogen (nitrate + nitrite), and $\sim 100 \mathrm{mg} \mathrm{h}^{-1}$ for free reactive phosphorus. Using these laboratoryderived rates and with 9 bags per plot, $43 \mathrm{~g} \mathrm{~d}^{-1}$ each of ammoniacal and oxidised nitrogen and $\sim 21 \mathrm{~g} \mathrm{~d}^{-1}$ of free reactive phosphorus were estimated to be released into each field plot per day. However, these release rates are a guide only, as rates in the field (and thus actual doses reaching seagrasses) may be affected by a variety of factors including water temperature, water flow, and cumulative epiphytic growth on bags. Thus, despite our attempts to provide a relatively constant supply of nutrients to the seagrass plots by using slow-release fertiliser and by regularly changing fertiliser bags, we did not know the precise nature of nutrient supply.

In addition to the leaching trial and to gain further understanding of nutrient exposure, nutrient levels in the overlying water column were assessed in winter (July 2005) and summer (February 2006) by taking a single water sample from directly adjacent to the centre bag in each of the 6 Posidonia experimental plots and (during winter only) at a single point $200 \mathrm{~m}$ from the plots. To assess the effect of immersion time on nutrient levels, 2 sets of water samples were collected; one just before replacement of bags (i.e. after they had been immersed for $1 \mathrm{mo}$ ), and another on the day after replacement with new fertiliser bags. Samples $(30 \mathrm{ml})$ were filtered $(0.45 \mu \mathrm{m})$ to remove particulate matter, and then frozen for later analysis. Dissolved concentrations of ammoniacal nitrogen, oxidised nitrogen, and free reactive phosphorus were measured at the Water Studies Centre at Monash University, Victoria, using flow injection analysis on a QuickChem 8000 Automated Ion Analyser.

Temperature at the site during the exposure phase ranged from about $12^{\circ} \mathrm{C}$ in winter (August 2005) to about $23^{\circ} \mathrm{C}$ in summer (January 2006). The site was characterised by high light intensity; for example, mean hourly photosynthetically active radiation on the seabed at solar noon across the period 18 January to 10 February 2006 was $661 \mu \mathrm{E} \mathrm{m}^{-2} \mathrm{~s}^{-1}$. While longterm data comparing water column light attenuation over fertiliser versus control plots were not collected, it is improbable that light attenuation over the fertiliser plots was significantly affected by localised increases in phytoplankton concentration. Springneap tidal ranges in the region of the experiment are of the order of 0 to $2 \mathrm{~m}$, with peak tidal currents of $>10 \mathrm{~cm} \mathrm{~s}^{-1}$ (authors' pers. obs.). Such currents would rapidly disperse any nutrient-mediated phytoplankton away from the fertiliser plots. 


\section{Experimental measurements}

Seagrasses were principally monitored over the entire course of the experiment by destructively harvesting and assessing samples of aboveground biomass from within experimental plots. Harvests were made before the bags were added $(0 \mathrm{mo})$ and then at 4 mo (winter 2005), 8 mo (summer 2005/06) and 12 mo (autumn 2006) during the exposure phase, and at 27 mo (winter 2007) after the start of the experiment (i.e. at the end of the recovery phase). Harvests consisted of three $25 \times 25 \mathrm{~cm}$ quadrats $\left(0.0625 \mathrm{~m}^{2}\right)$ being placed haphazardly within plots, while taking care not to resample previously harvested points (which were marked after each harvest). Harvests were made by cutting all aboveground seagrass material within the quadrat area at the level of the substratum, and then placing these in a numbered plastic bag. For Amphibolis antarctica, the aboveground seagrass material comprised emergent vertical rhizomes (or stems) with their associated branches and leaf clusters, while for Posidonia sinuosa, it was only emergent leaves. Bags were placed on ice for return to the laboratory, and thereafter frozen at $-30^{\circ} \mathrm{C}$ until processing. At $8 \mathrm{mo}$, a modified sampling protocol was used whereby stem and leaf density was estimated in situ using the quadrats, but at the same time, 15 random stems (in A. antarctica) and leaves (in P. siunuosa) were removed from each area to be assessed for epiphytes and seagrass biomass. Just prior to the completion of the experiment at $27 \mathrm{mo}$, a total of 9 quadrats of $0.0625 \mathrm{~m}^{2}$ had been harvested from each $2.25 \mathrm{~m}^{2}$ plot, such that $25 \%$ of the total area had been affected by destructive harvesting. We assumed that this repeated sampling did not have a detrimental effect on the remaining seagrass within the experimental plots (see 'Discussion').

Amphibolis antarctica has wiry stems and branches with leaf clusters, while Posidonia sinuosa has strap-like leaves that emerge from basal leaf sheaths. For both species, measurements were made of aboveground seagrass biomass (stems, branches and leaves in $A$. antarctica, leaves in $P$. sinuosa) (g dry weight $[\mathrm{DW}] \mathrm{m}^{-2}$ ), stem (in A. antarctica) or leaf (in $P$. sinuosa) density (no. $\mathrm{m}^{-2}$ ), canopy height (cm), epiphyte load (g DW epiphytes:g DW seagrass), and epiphyte composition (grouped into 4 broad algal groups; reds, greens, browns, corallines). Due to morphological differences, epiphyte load in A. antarctica included epiphytes on the stems, branches and leaves, while in $P$. sinuosa it was for leaves only. Canopy height in A. antarctica was measured as the mean distance from the stem base to the tip of the highest leaf cluster from multiple randomly selected stems, while in $P$. sinuosa it was the mean distance from the leaf base to the leaf tip from multiple randomly selected leaves (i.e. they were mean canopy heights and not maximum or $80 \%$ canopy heights, as sometimes reported in other studies). Due to the large amount of biomass within quadrats, subsamples were generally used to estimate most of the variables for the 2 species. Epiphyte load and seagrass biomass were calculated from DW ( $3 \mathrm{~d}$ drying at $60^{\circ} \mathrm{C}$ ) of scraped epiphytes and epiphyte-free seagrass.

At 12 mo, additional measurements for Amphibolis antarctica were made of the number of leaf clusters per stem, and the number of leaves per terminal leaf cluster i.e. highest cluster on the main stem. Terminal clusters were chosen in an attempt to standardise for the potential effects of self-shading caused by differences in canopy structure amongst quadrats and treatments. Whilst the effects of grazing were not a major focus of our study, at the 12 mo stage, all visible gastropods $(>2 \mathrm{~mm})$ that were attached to harvested seagrass material were also collected, identified, measured, counted and then converted to gastropod density (no. $\mathrm{m}^{-2}$ ) and gastropod frequency (no. gastropods $\mathrm{g} \mathrm{DW}^{-1}$ aboveground biomass, i.e. seagrass + epiphytic material). We did not sample other potential but more mobile grazers such as isopods and amphipods.

During winter (June and July 2005) and summer (January and February 2006) of the exposure phase, measurements were made of leaf initiation rate in Amphibolis antarctica and leaf elongation rate in Posidonia sinuosa. A. antarctica was assessed using the method of Walker (1985), whereby the initiation rate of new leaves is quantified by tagging leaf clusters with twist ties. In each plot, a total of 5 (in winter) and 12 (in summer) discrete leaf clusters on separate A. antarctica stems were randomly selected, tagged and then re-assessed in situ after ca. 1 mo. Due to loss of individual leaf cluster labels during this time, data were pooled for each plot to calculate mean number of new leaves per day. P. sinuosa was assessed with a hole-punch method (Kirkman \& Reid 1979) utilising a hypodermic needle to mark 2 small holes at the base of leaves just above the leaf sheath such that the vertical movement of the holes could be followed and measured in situ after ca. 1 mo. Five and 10 sheaths per plot were randomly selected and marked in winter and summer, respectively. For the winter assessment, only sheaths with a single leaf were marked, while in summer sheaths with 1 or more leaves were marked. The change in technique was due to a noted 
deficiency in the winter technique that was then rectified for the following summer. Elongation rate for the winter period relates only to the movement of each single leaf (and ignores the initiation of any new leaves), while in summer the elongation rate accounted for all tagged leaves as well as the length of any new leaves initiated post-marking. Thus it was not possible to meaningfully compare winter and summer values of leaf elongation rate in Posidonia.

During summer (January 2006) of the exposure phase, seagrass photosynthetic efficiency was assessed using an underwater pulse-amplitude modulated (diving-PAM) fluorometer (Ralph et al. 1998) to measure effective quantum yield during the day (15:45 to $17: 00 \mathrm{~h})$ and maximal quantum yield at night just prior to dawn (03:45 to 04:45 h). Measures of photosynthetic yield can indicate if seagrasses are stressed (Seddon \& Cheshire 2001). A single reading was taken on each of 10 randomly selected stems or leaves within each plot. Readings were made at the tops of Amphibolis antarctica leaf clusters and at $\sim 3 \mathrm{~cm}$ above the base of Posidonia sinuosa leaves, where epiphytes were absent but green photosynthetic seagrass material was present. All pre-dawn measurements were carried out using low intensity torches with a red filter. At the 12-mo stage of the exposure phase, an assessment was also made of the strength of $P$. sinuosa leaves using a purpose-built breaking strain device. Fifteen randomly selected leaves pooled from 2 fertiliser and 2 control plots were tested for their breaking strain (mass required to snap or tear a leaf) at a location $15 \mathrm{~cm}$ above the leaf base. Samples were kept in seawater until immediately prior to testing at $<12 \mathrm{~h}$ post-harvest.

To investigate if seagrasses in fertiliser treatments were accumulating nutrients to a greater extent than control treatments, a subsample of leaves was collected from the treatment plots during winter of the exposure phase. Samples were kept on ice until returned from the field, after which they were kept in a $-30^{\circ} \mathrm{C}$ freezer. Epiphytes were then removed using a blade. A section of leaf $(\sim 5 \mathrm{~cm}$ long) was then taken, placed in a vial and returned to the freezer. Samples were freeze-dried overnight and then ground to a fine powder using a Fritsch stainless steel ball mill. Chemical analysis was carried out at the Marine and Freshwater Research Laboratory, Murdoch University, Western Australia. Total Kjeldahl nitrogen (mg $\mathrm{N} \mathrm{g}^{-1}$ ) and total phosphorus (mg $\mathrm{P} \mathrm{g}^{-1}$ ) were determined through digestion and subsequent analysis for ammonia and orthophosphate, respectively, via Flow Injection Analysis on a Lachat QC8000.

\section{Data analysis}

Experimental measurements were designed to determine the effect of elevated nutrients on the seagrasses and epiphytes during the exposure phase and following the recovery phase. Of main interest was the effect of nutrients on seagrass biomass, density, canopy height, and epiphyte load at 0 mo (start of experiment), at 12 mo (near the end of the exposure phase) and at 27 mo (end of recovery phase). It is the relative difference between the fertiliser and control treatments at each of those individual times $(0,12,27 \mathrm{mo})$ that is the critical measure as it accounts for natural temporal fluctuations that are known to occur in the seagrass variables of biomass, density, canopy height and epiphyte load. However, some comparisons could only be made at one point in time when data were available, i.e. leaf cluster frequency, leaf frequency, rates of leaf initiation and elongation, effective and maximal quantum yield, percentage nitrogen and phosphorus content, breaking strain of leaves and gastropod frequency. In these cases, it had to be assumed that there was no significant difference between control and fertiliser treatments at the start of the experiment. All data analyses were conducted separately for Amphibolis antarctica and Posidonia sinuosa due to their differing morphology and physiology.

A nested or hierarchical ANOVA design was chosen to analyse much of the data where there were 3 quadrats within each plot and 3 plots within each of the 2 treatments. While there were only 3 plots per treatment, the nested design (with 9 quadrats in total) makes the analysis quite robust as it accounts for small-scale spatial variability within plots as well as variability amongst plots. The nested design requires each quadrat to be independent, which was taken to be a valid assumption (see later for discussion). As the variables of seagrass biomass, density, canopy height and epiphyte load were all measured from the same quadrats, a 2-way nested multivariate analysis of variance (MANOVA) was first used with the following model: Treatment + Time + Treatment $\times$ Time + Plot (Treatment) + Time $\times$ Plot (Treatment), where Treatment (Control or Fertiliser) and Time (0, 12 or 27 mo) were fixed factors and plot was random (note that canopy height was not included in the MANOVA for Amphibolis antarctica as the 0 mo data were missing). Where the MANOVA was significant $(p<0.05)$ for any of the main effects or their interaction, separate ANOVAs using the same model were then run on each variable separately. In the separate ANOVA tests, we were principally interested in the main ef- 
fects interaction term (i.e. Treatment $\times$ Time), and if this was significant (along with the main effect of Treatment) then separate 1-way ANOVAs were used at each point in time (i.e. 0, 12 or $27 \mathrm{mo}$ ) to test the main effect of Treatment with the following simple model: Treatment + Plot (Treatment). A significant result at 12 mo was deemed to indicate an effect of the fertiliser due to nutrient exposure, while a significant result at 27 mo would indicate a lack of recovery following nutrient exposure. The same ANOVA model was also used for testing the effects of nutrient addition on leaf cluster frequency, leaf frequency, rates of leaf initiation and elongation, effective and maximal quantum yield, and gastropod density and frequency. As nitrogen and phosphorus content were measured from the same leaves, a MANOVA was used first and if this was significant, separate ANOVAs were then used for each nutrient species. Breaking strain of Posidonia sinuosa was analysed with a Student's $t$-test. Due to large temporal and spatial fluctuations in ambient nutrient conditions, comparisons of nutrient concentrations in fertiliser versus control treatments are meaningful only for each individual time period, i.e. winter $1 \mathrm{~d}$, winter $1 \mathrm{mo}$, summer $1 \mathrm{~d}$, summer $1 \mathrm{mo}$. Thus, separate comparisons were conducted for each nutrient species and time period using Student's $t$-tests. Before conducting any of the statistical tests mentioned above, assumptions of the tests were firstly validated. Where data failed validation, they were transformed to remedy the situation.

To test for differences in epiphyte composition (reds, greens, browns, corallines) between treatments, multivariate analyses (PRIMER V6) were performed on un-transformed proportional data for each species and time period separately. Plot level data only were available for the 8 mo period $(n=3$ per treatment), but quadrat level data were available for 12 mo ( $n=9$ per treatment). Differences in Bray-Curtis dissimilarity measures were tested using an analysis of similarities (ANOSIM), followed by a similarity percentage (SIMPER) analysis to identify the algal group(s) contributing most to any significant differences between treatments.

\section{RESULTS}

\section{Experimental conditions}

Water column nutrient levels were consistently elevated in the fertiliser treatments in comparison to the control treatments during the exposure phase; at both $1 \mathrm{~d}$ and 1 mo after fertiliser bags were changed
(Fig. 2). The magnitude of nutrient increase in the fertiliser treatment at any given time was generally $<10 \times$ the concentration in the control treatment (Fig. 2). A major exception to the average situation occurred $1 \mathrm{~d}$ after the fertiliser bags were changed during summer, when free reactive phosphorus was 26x higher in fertilised plots than controls (Fig. 2); nonetheless, the high mean value was influenced greatly by a single plot with a value of $0.025 \mathrm{mg} \mathrm{P}^{-1}$. Assuming that the 4 measurement times were representative of conditions during the 15 mo exposure phase, average levels of ammoniacal nitrogen, oxidised nitrogen and free reactive phosphorus, respectively, were $0.0263,0.0247$ and $0.0063 \mathrm{mg} \mathrm{l}^{-1}$ in fertiliser plots, and $0.0080,0.0113$ and $0.0014 \mathrm{mg} \mathrm{l}^{-1}$ in
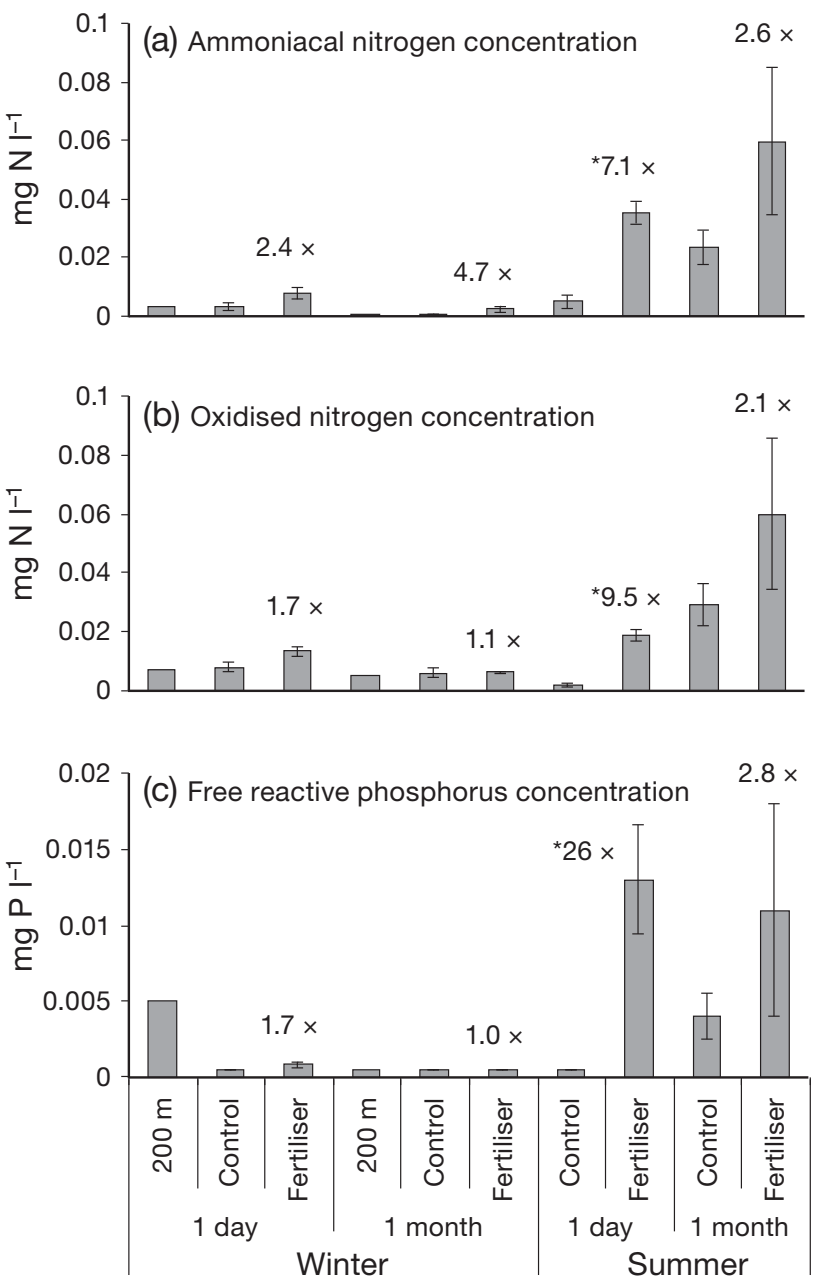

Fig. 2. Concentrations (mean $\pm S E, n=3$ ) of dissolved nutrients in control and fertiliser experimental treatments and at a site $200 \mathrm{~m}$ away from the experimental plots $(\mathrm{n}=1)$, at $1 \mathrm{~d}$ and 1 mo after replacing fertiliser bags during winter and summer of the nutrient exposure phase. Values above columns indicate the magnitude of nutrient increase for fertiliser versus control treatment at each time period $\left({ }^{*}\right.$ indicates a significant difference between the mean values, $t$-tests: $p<0.05$ ) 
control plots. Thus nutrient levels were about 3, 2 and $5 \times$ higher in fertiliser plots than control plots for ammoniacal nitrogen, oxidised nitrogen and free reactive phosphorus, respectively.

There was generally no indication that nutrients in the control plots were also elevated relative to a site $200 \mathrm{~m}$ outside the experimental area during winter (Fig. 2; it is unclear why the value for free reactive phosphorus at $200 \mathrm{~m}$ after $1 \mathrm{~d}$ in winter was so elevated). Thus the effect of the fertiliser bags appeared to be quite localised and the control plots could be considered to be independent of the fertiliser plots. In addition, the visual effect of elevated nutrients on epiphytes in fertiliser plots was highly localised (authors' pers. obs.); further evidence that the fertiliser bags were influencing the fertiliser plots only and not the adjacent control plots.

\section{Effect on seagrasses}

In both Amphibolis antarctica and Posidonia sinuosa, elevated nutrients had a significant detrimental effect on seagrass biomass, density and canopy height (Fig. 3, Tables $1 \& 2$; MANOVA results preceding ANOVAs: $A$. antarctica Treatment $F_{3,33}=42.195$, $\mathrm{p}<0.001$; Time $F_{6,68}=9.738, \mathrm{p}<0.001$; Treatment $\times$ Time $F_{6,68}=17.054, \mathrm{p}<0.001 ; P$. sinuosa Treatment $F_{4,33}=24.607, \mathrm{p}<0.001 ;$ Time $F_{8,68}=359.330, \mathrm{p}<$ 0.001 ; Treatment $\times$ Time $\left.F_{8,68}=14.920, \mathrm{p}<0.001\right)$. After $12 \mathrm{mo}$, seagrass biomass and density in the fertiliser treatments were about $20 \%$ and $45 \%$ (for $A$. antarctica) and $30 \%$ and $50 \%$ (for P. sinuosa), respectively, of values found in the control treatments. At $27 \mathrm{mo}$, following the recovery period, seagrass biomass, density and canopy height were all still significantly lower in the fertiliser treatments of both species (Fig. 3, Tables 1 \& 2). At 12 mo, the remaining $A$. antarctica stems in the fertiliser treatment also had significantly less leaf clusters per stem and less leaves per cluster than the controls $(3.1 \pm 0.62$ versus $6.9 \pm$ 1.3 [mean $\pm \mathrm{SE}$ ] clusters per stem, $F_{1,12}=40.974, \mathrm{p}<$ $0.001 ; 6.0 \pm 0.15$ versus $8.1 \pm 0.45$ leaves per cluster, $\left.F_{1,12}=26.599, \mathrm{p}<0.001\right)$.

Addition of fertiliser had no significant effect on Amphibolis antarctica leaf initiation rate (mean values in summer and winter of $\sim 0.03$ to 0.06 new leaves $\mathrm{d}^{-1}$ ) or Posidonia sinuosa leaf elongation rate (mean values in summer of $\sim 3$ to $4 \mathrm{~mm} \mathrm{~d}^{-1}$; all tests: $\mathrm{p}>0.05$ ). There was no significant difference in leaf breaking strain for $P$. sinuosa ( $\mathrm{p}>0.05)$.

Measures of photosynthetic yield showed no significant difference between control and fertiliser treat- ments for either species (all tests: $p>0.05$ ). Nitrogen and phosphorus content in the leaves of both species appeared slightly higher in the fertiliser than control treatments (nitrogen means: Amphibolis antarctica control $=1.6 \%$, fertiliser $=2.0 \%$, Posidonia sinuosa control $=1.7 \%$, fertiliser $=2.0 \%$; phosphorus means: A. antarctica control $=0.08 \%$, fertiliser $=0.15 \%, P$. sinuosa control $=0.13 \%$, fertiliser $=0.13 \%$ ), but only phosphorus in $A$. antarctica was statistically significant $\left(F_{1,3}=30.146, \mathrm{p}=0.012\right)$. However, the absolute values for phosphorus in $A$. antarctica were extremely low and the level of phosphorus in the fertiliser treatment was only $1.9 \times$ higher than the control.

\section{Effect on epiphytes}

Addition of nutrients significantly increased epiphyte loads on both seagrass species during the exposure phase (Fig. 3d,h, Table 1). At 8 mo, epiphyte load was $20 \times$ and $5 \times$ higher in the fertiliser treatments of Amphibolis antarctica and Posidonia sinuosa, respectively. At the end of the recovery phase (27 mo), epiphyte loads in the fertiliser treatments had returned to levels comparable to the control treatments (Fig. 3d,h), providing further evidence that nutrients had been exhausted in the fertiliser bags since their final replenishment at 12 mo. However, the epiphyte load of $P$. sinuosa was surprisingly significantly greater in the fertiliser treatment at 27 mo (Table 1).

The composition of epiphytes at 8 and 12 mo was markedly different between the control and fertiliser treatments for both seagrasses (Fig. 4). For Amphibolis antarctica, the control treatment at both 8 and 12 mo was comprised mainly of red and coralline algae in about equal proportions with an absence of green algae, while the fertiliser treatment was dominated by red algae, with some green algae present at 12 mo (Fig. 4; at 8 mo, ANOSIM Global R =0.852, $\mathrm{p}=0.01$, SIMPER red $=49 \%$ and red + coralline $=92 \%$ contribution to differences between treatments; at $12 \mathrm{mo}$, ANOSIM Global $\mathrm{R}=0.419, \mathrm{p}=0.001$, SIMPER coralline $=45 \%$, coralline + red $=86 \%$ contribution to differences).

For Posidonia sinuosa, the control treatment after 8 mo was comprised mainly of brown and coralline algae, with some red algae present, while in the fertiliser treatment, green and red algae were dominant (Fig. 4; ANOSIM Global $\mathrm{R}=0.852$, $\mathrm{p}=0.01$; SIMPER green $=37 \%$ and green + brown $=61 \%$ contribution to differences between treatments). At 12 mo in $P$. sinuosa, the control treatment was comprised mainly 

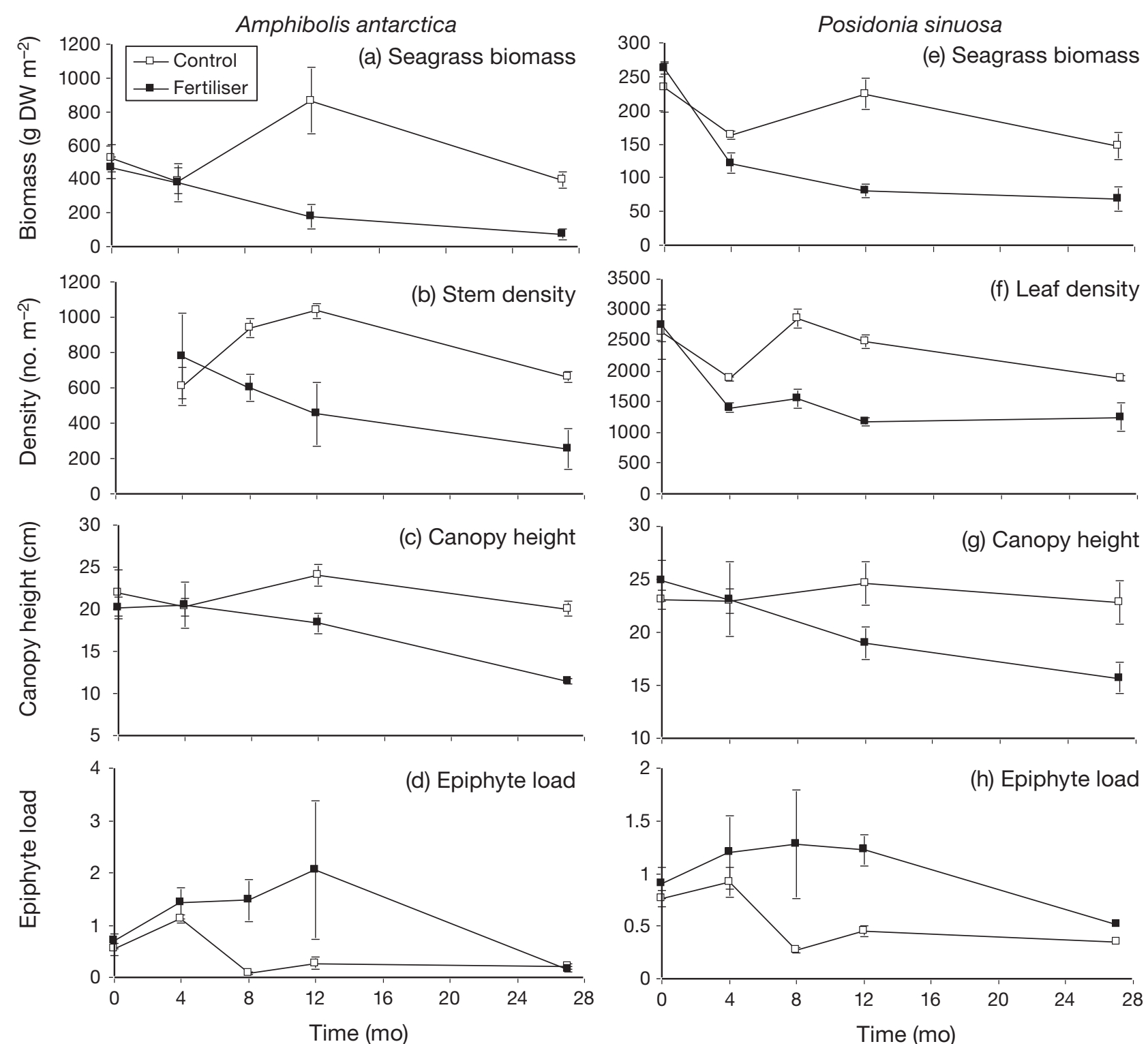

Fig. 3. Amphibolis antarctica and Posidonia sinuosa. Amphibolis antarctica (a) seagrass biomass, (b) stem density, (c) canopy height and (d) epiphyte load, and Posidonia sinuosa (e) seagrass biomass, (f) leaf density, (g) canopy height and (h) epiphyte load in control and fertiliser treatments across a 15 mo nutrient exposure phase ( 0 to 15 mo) and a 12 mo recovery phase (15

to $27 \mathrm{mo})$. Values are mean $\pm \mathrm{SE}(\mathrm{n}=3)$. Note that stem density data for A. antarctica at 0 mo are unavailable

of red algae with some green and brown algae, while both red and green algae dominated the fertiliser treatment (Fig. 4; ANOSIM Global $\mathrm{R}=0.778, \mathrm{p}=$ 0.001 ; SIMPER green $=46 \%$ and green + red $=91 \%$ contribution to differences).

\section{Links between epiphytes and seagrass decline}

For both seagrass species, the temporal pattern of seagrass biomass closely followed the pattern of epiphyte load within each of the control and fertiliser treatments during the exposure phase. From 0 to $4 \mathrm{mo}$, epiphyte load increased in both treatments and seagrass biomass declined. However, after 4 mo when epiphyte load decreased in the controls, seagrass biomass increased, but when epiphyte load was maintained at a higher level in the fertiliser treatment, biomass continued to decline (Fig. 3). Indeed, for the time periods when seagrass biomass and epiphyte load data are both available (0 to 4 and 4 to $12 \mathrm{mo}$ ), there is a highly significant negative linear relationship ( $\left.p=0.002, r^{2}=0.81\right)$ between the change in seagrass biomass and the change in epiphyte load 
Table 1. Amphibolis antarctica and Posidonia sinuosa. ANOVA tests for seagrass biomass, density, canopy height and epiphyte load among nutrient treatment, time and plot. Error df is 36 for P. sinuosa, 35 for A. antarctica (as 1 quadrat had no seagrass at 27 mo and was by necessity excluded from the analysis), and 24 for density (as data were available only for 12 and 27 mo and the zero quadrat was included in this analysis). Trt: nutrient treatment. Significant $\mathrm{p}$-values are in bold

\begin{tabular}{|c|c|c|c|c|c|c|c|}
\hline \multirow[t]{2}{*}{ Variable } & \multirow[t]{2}{*}{ Source } & \multicolumn{3}{|c|}{- A. antarctica - } & \multicolumn{3}{|c|}{$-P$. sinuosa } \\
\hline & & $\mathrm{df}$ & $F$ & $\mathrm{p}$ & df & $F$ & $\mathrm{p}$ \\
\hline \multirow{5}{*}{$\begin{array}{c}\text { Seagrass } \\
\text { biomass }\end{array}$} & Trt & 1 & 74.252 & $<0.001$ & 1 & 1.300 & 0.262 \\
\hline & Time & 2 & 23.096 & $<0.001$ & 2 & 398.013 & $<0.001$ \\
\hline & Trt $\times$ Time & 2 & 17.043 & $<0.001$ & 2 & 36.434 & $<0.001$ \\
\hline & Plot(Trt) & 4 & 5.346 & 0.002 & 4 & 1.042 & 0.399 \\
\hline & Time $\times$ Plot $($ Trt $)$ & 8 & 1.581 & 0.166 & 8 & 1.948 & 0.082 \\
\hline \multirow[t]{5}{*}{ Density } & Trt & 1 & 50.195 & $<0.001$ & 1 & 30.262 & $<0.001$ \\
\hline & Time & 1 & 14.165 & 0.001 & 2 & 30.269 & $<0.001$ \\
\hline & Trt $\times$ Time & 1 & 0.002 & 0.963 & 2 & 12.563 & $<0.001$ \\
\hline & Plot(Trt) & 4 & 5.301 & 0.003 & 4 & 1.571 & 0.203 \\
\hline & Time $\times$ Plot(Trt) & 4 & 1.111 & 0.374 & 8 & 1.806 & 0.108 \\
\hline \multirow{5}{*}{$\begin{array}{l}\text { Canopy } \\
\text { height }\end{array}$} & Trt & 1 & 62.561 & $<0.001$ & 1 & 18.233 & $<0.001$ \\
\hline & Time & 2 & 30.086 & $<0.001$ & 2 & 1382.603 & $<0.001$ \\
\hline & Trt $\times$ Time & 2 & 12.249 & $<0.001$ & 2 & 9.743 & $<0.001$ \\
\hline & Plot(Trt) & 4 & 2.044 & 0.109 & 4 & 4.523 & 0.005 \\
\hline & Time $\times$ Plot(Trt) & 8 & 1.049 & 0.420 & 8 & 0.525 & 0.830 \\
\hline \multirow{5}{*}{$\begin{array}{l}\text { Epiphyte } \\
\text { load }\end{array}$} & Trt & 1 & 22.264 & $<0.001$ & 1 & 50.068 & $<0.001$ \\
\hline & Time & 2 & 46.467 & $<0.001$ & 2 & 29.851 & $<0.001$ \\
\hline & Trt $\times$ Time & 2 & 28.123 & $<0.001$ & 2 & 12.053 & $<0.001$ \\
\hline & Plot(Trt) & 4 & 7.094 & $<0.001$ & 4 & 1.528 & 0.215 \\
\hline & Time $\times$ Plot $($ Trt $)$ & 8 & 3.635 & 0.004 & 8 & 0.895 & 0.530 \\
\hline
\end{tabular}

Table 2. Amphibolis antarctica and Posidonia sinuosa. ANOVA tests for seagrass biomass, density, canopy height and epiphyte load among nutrient treatment and plot. Test results for stem density in A. antarctica are not shown as there was no significant interaction of Treatment $\times$ Time across 12 and 27 mo - see Table 1 . In all cases, the error df is 12 , except $A$. antarctica at 27 mo when df is 11 (as 1 quadrat had no seagrass at 27 mo and was by necessity excluded from the analysis). Trt: nutrient treatment. Significant p-values are in bold

\begin{tabular}{|c|c|c|c|c|c|c|c|c|}
\hline \multirow[t]{2}{*}{ Variable } & \multirow[t]{2}{*}{ Source } & \multirow[t]{2}{*}{ df } & \multicolumn{2}{|c|}{$-0 \mathrm{mo}-$} & \multicolumn{2}{|c|}{$-12 \mathrm{mo}-$} & \multicolumn{2}{|c|}{$-27 \mathrm{mo}-$} \\
\hline & & & $F$ & $\mathrm{p}$ & F & $\mathrm{p}$ & F & $\mathrm{p}$ \\
\hline \multicolumn{9}{|c|}{ A. antarctica } \\
\hline \multirow{2}{*}{$\begin{array}{c}\text { Seagrass } \\
\text { biomass }\end{array}$} & Trt & 1 & 0.071 & 0.795 & 52.016 & $<0.001$ & \multicolumn{2}{|c|}{$48.103<\mathbf{0 . 0 0 1}$} \\
\hline & Plot(Trt) & 4 & 0.280 & 0.885 & 4.681 & 0.017 & 3.076 & 0.063 \\
\hline \multirow{2}{*}{$\begin{array}{c}\text { Canopy } \\
\text { height }\end{array}$} & Trt & 1 & 2.509 & 0.139 & 13.087 & 0.004 & \multicolumn{2}{|c|}{$65.560<\mathbf{0 . 0 0 1}$} \\
\hline & Plot(Trt) & 4 & 4.470 & 0.019 & 0.697 & 0.609 & 0.507 & 0.732 \\
\hline \multirow{2}{*}{$\begin{array}{l}\text { Epiphyte } \\
\text { load }\end{array}$} & & 1 & 2.320 & 0.154 & 61.826 & $<0.001$ & \multirow{2}{*}{$\begin{array}{l}2.098 \\
4.154\end{array}$} & 0.175 \\
\hline & Plot(Trt) & 4 & 2.095 & 0.145 & 6.730 & 0.004 & & 0.027 \\
\hline \multicolumn{9}{|l|}{ P. sinuosa } \\
\hline \multirow{2}{*}{$\begin{array}{l}\text { Seagrass } \\
\text { biomass }\end{array}$} & Trt & 1 & 0.720 & 0.413 & 62.143 & $<0.001$ & \multicolumn{2}{|c|}{$34.306<\mathbf{0 . 0 0 1}$} \\
\hline & Plot(Trt) & 4 & 0.413 & 0.796 & 1.133 & 0.387 & 3.991 & 0.028 \\
\hline \multirow{2}{*}{$\begin{array}{l}\text { Leaf } \\
\text { density }\end{array}$} & Trt & 1 & 0.285 & 0.603 & 53.613 & $<0.001$ & \multirow{2}{*}{$\begin{array}{r}11.474 \\
1.884\end{array}$} & 0.005 \\
\hline & Plot(Trt) & 4 & 2.524 & 0.096 & 0.401 & 0.804 & & 0.178 \\
\hline \multirow{2}{*}{$\begin{array}{c}\text { Canopy } \\
\text { height }\end{array}$} & Trt & 1 & 0.686 & 0.424 & 15.013 & 0.002 & \multirow{2}{*}{$\begin{array}{r}33.198 \\
4.069\end{array}$} & $<0.001$ \\
\hline & Plot(Trt) & 4 & 0.602 & 0.669 & 2.083 & 0.146 & & 0.02 \\
\hline \multirow{2}{*}{$\begin{array}{l}\text { Epiphyte } \\
\text { load }\end{array}$} & Trt & 1 & 0.810 & 0.386 & 62.143 & $<0.001$ & \multirow{2}{*}{$\begin{array}{r}23.265 \\
2.031\end{array}$} & $<0.001$ \\
\hline & Plot(Trt) & 4 & 0.820 & 0.537 & 1.133 & 0.387 & & 0.154 \\
\hline
\end{tabular}

(Fig. 5). There were also clear differences in epiphyte composition between fertiliser and control treatments that might also be linked to the seagrass declines (Figs. $3 \& 4$ ).

\section{Effect on gastropod grazers}

While gastropod frequency was not assessed at the commencement of the experiment, considerable numbers of prosobranch gastropod grazers were found at the 12 mo stage of the exposure phase (ranges of 8 to 95 and 0 to 9 per quadrat and totals of 619 and 47 across all plots for Amphibolis antarctica and Posidonia sinuosa, respectively). Gastropod density (no. $\mathrm{m}^{-2}$ ) showed no significant difference between fertiliser and control treatments for either species (A. antarctica, $\mathrm{p}>0.05$; P. sinuosa, $\mathrm{p}>0.05$; Fig. 6). However, when vegetative biomass is accounted for, gastropod frequency (gastropod numbers as a function of epiphyte + seagrass aboveground biomass) was significantly greater in the fertiliser treatments of both seagrasses $(1.5 \times$ greater for $A$. antarctica, $F_{1,12}=19.311, \mathrm{p}=0.001 ; 3 \times$ greater for P. sinuosa, $F_{1,12}=14.142, \mathrm{p}=0.003$; Fig. 6). Gastropods ranged in size from 2 to $15 \mathrm{~mm}$, comprising mainly 3 species, Astralium aureum, Phasianotrochus irisodontes and juvenile Thalotia chlorostoma, that collectively accounted for $88 \%$ and $95 \%$ of all gastropods in the A. antarctica and $P$. sinuosa plots, respectively.

\section{DISCUSSION}

\section{Nutrient-mediated epiphytes caused seagrass declines}

Through manipulative experimentation in the field, we were able to demonstrate significant declines in both Amphibolis antarctica and Posidonia sinuosa in response to chronic, yet minor, increases in water column 


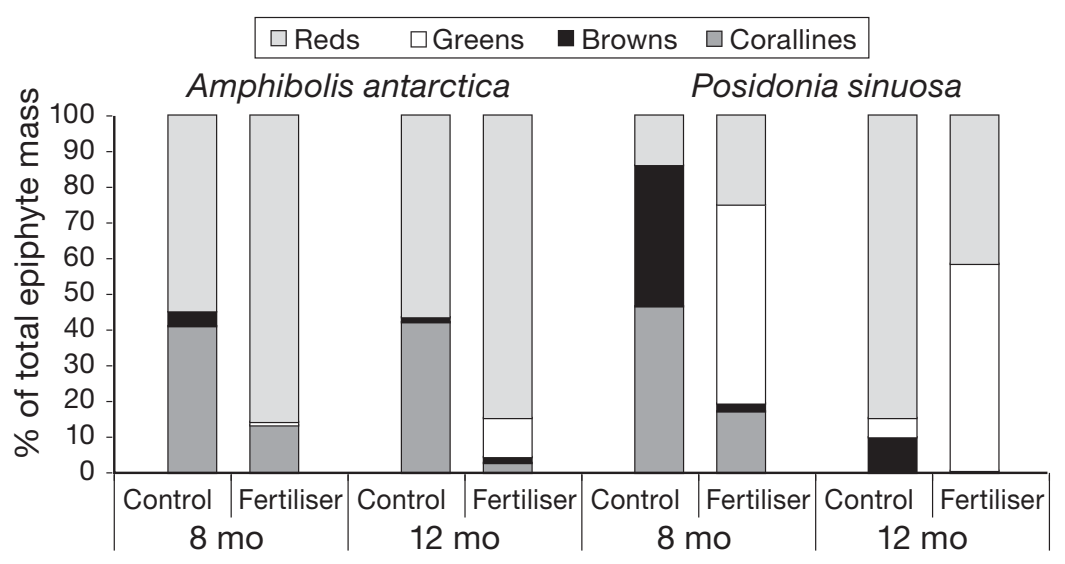

Fig. 4. Amphibolis antarctica and Posidonia sinuosa. Composition of epiphytic algae in control and fertiliser treatments at 8 and 12 mo of the nutrient exposure phase. Reds, greens, browns and corallines refer to the 4 different groups of algae identified. Plotted values are means from the 3 plots per treatment
'Materials and methods'). Furthermore, we did not observe or sample any drift macroalgae smothering the seagrasses. Our data do not support the idea of a toxic response to the nutrient increases. If a toxic response was occurring in the fertiliser plots, then we might expect reduced growth and lowered photosynthetic efficiency (Ralph et al. 2006), neither of which was observed. It is also possible that increased nutrients could have caused increased nitrogen uptake leading to internal imbalances and structural damage (Ralph et al. 2006). However, the fertilised seagrasses had only slightly raised levels of nitrogen (non-significant for both species) and phosphorus (significant for Amphibolis antarctica only), indicating neither a major imbalance nor that they were being sequestered in toxic amounts. Furthermore, the Posidonia sinuosa fertilised shoots demonstrated no evidence of structural damage at the meristem (cf. Burkholder et al. 1992) because shoots continued to produce leaves at
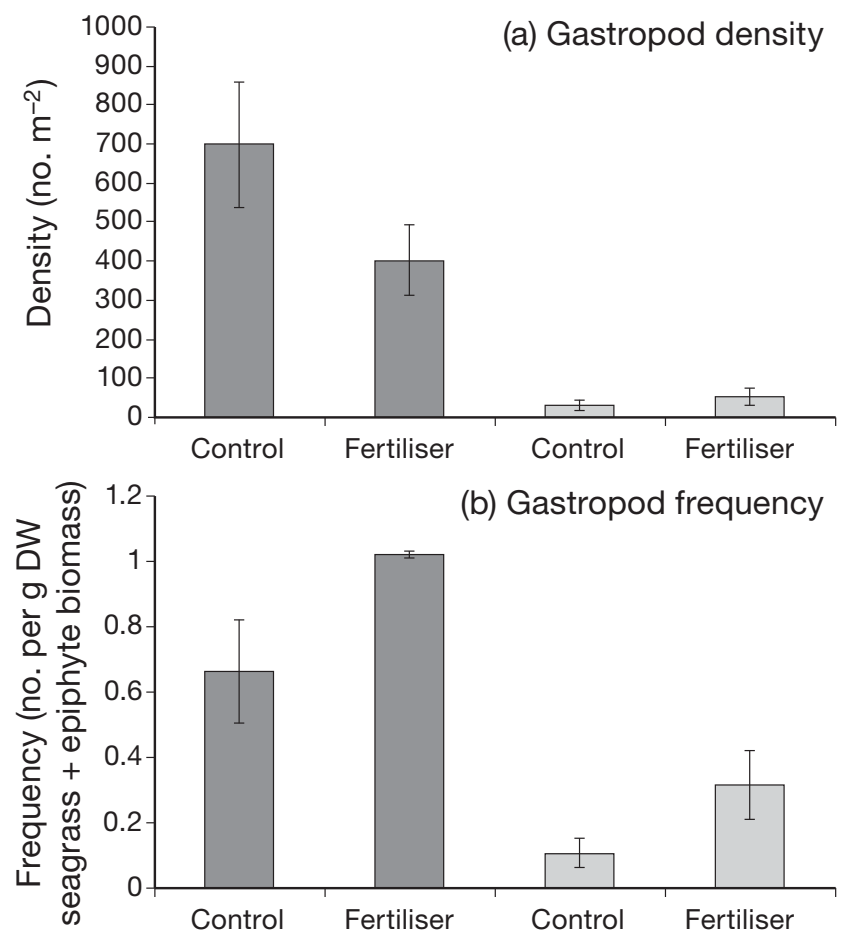

Fig. 6. Amphibolis antarctica and Posidonia sinuosa. Gastropod (a) density and (b) frequency (mean $\pm \mathrm{SE}, \mathrm{n}=3$ ) of $A$. antarctica (dark columns) and $P$. sinuosa (light columns) in control and fertiliser treatments at the 12 mo stage of the nutrient exposure phase 
normal rates. There was also no difference in the breaking strength of $P$. sinuosa leaves between fertiliser and control treatments. In addition, our measured levels of water column nutrients around the fertiliser treatments were not drastically elevated ( 2 to $5 \times$ ambient); whereas toxic responses in laboratory trials often occur when using toxicant levels that are unlikely in the field (Ralph et al. 2006).

Mesograzers can play either a positive role by suppressing epiphytes and increasing seagrass productivity, or a negative role by directly consuming seagrasses (Hughes et al. 2004, Valentine \& Duffy 2006, Heck \& Valentine 2007). However, we discount increased herbivory as the primary cause of our observed seagrass declines. The seagrasses in our fertiliser treatments were not significantly enriched with nitrogen that could potentially make them more palatable to grazers (Goecker et al. 2005, Heck \& Valentine 2007), and we found only minor evidence of direct grazing on the tips of new Amphibolis antarctica leaves during summer and no evidence of direct grazing on Posidonia sinuosa. While we did not quantify potential grazers other than gastropods and some impact from direct grazing cannot be completely discounted, we observed no large seagrass grazers (e.g. seaurchins, Larkum \& West 1990; seastars, Shepherd et al. 1989; leatherjackets, Wressnig and Booth 2008) in our experimental plots over a considerable number of visits.

It is most likely that the small gastropods $(\leq 15 \mathrm{~mm}$ length) we documented were actually feeding on the epiphytes rather than the seagrasses, with the increased gastropod frequencies in the fertiliser treatments (Fig. 6) being related to the increased epiphyte loads. The 3 dominant gastropods that we found are all normal inhabitants of southern Australian seagrass ecosystems (Wilson 1993, Edgar 1997). While Keuskamp (2004) found that gastropod grazers (>7 mm) do not appear to play a major role in controlling seagrass epiphytes in oligotrophic environments in South Australia, he did find that gastropod grazing maintained the abundance of filamentous algae on Posidonia sinuosa. In addition, Jernakoff \& Nielsen (1997) present some evidence that gastropod grazing of epiphytes can enhance leaf survival in P. sinuosa. Thus, the presence of slightly increased gastropod frequencies (in relation to aboveground biomass) in the fertiliser treatments of our experiment may well have reduced epiphyte biomass, thereby slowing the apparent detrimental effects of increased epiphyte load or changed epiphyte composition (see Baggett et al. 2010). As direct grazing of Amphibolis spp. and Posidonia spp. is proba- bly unimportant locally and the level of epiphytic grazing appeared minor at our experimental site, topdown effects (including any major reductions in larger marine consumers of seagrass or epiphytic grazers that may have occurred in the region, Heck \& Valentine 2007) appear unlikely to have played a major role in our experimental results.

It could be argued that 2 key factors of our experimental design caused confounding effects that influenced both our observations and interpretations: (1) the repeated destructive sampling or cropping in our experimental plots, and (2) the decision to treat quadrats within plots as independent replicates. Both Amphibolis and Posidonia are clonal seagrasses that have underground rhizomes that provide both physical and physiological connections between aboveground structures (Marbà et al. 2002, Prado et al. 2008b). Due to potential physiological connections it is possible that the cropping of neighbouring seagrass contributed to the observed responses of remaining seagrasses in the 2 treatments, and also that the quadrats were in fact not independent.

In terms of cropping, a response of fertiliser addition on seagrasses was observed at 8 and 12 mo (Fig. 3) when only $17 \%$ of the total area had been harvested (only 2 full harvests 0 and 4 had occurred prior to the 8 and 12 mo measurements - see 'Materials and methods'). Indeed, even after several harvests had occurred, it was still difficult to locate the control plots of both seagrass species at 12 and 27 mo, i.e. previous harvesting had not created obvious bare zones. Nonetheless, it is possible that cropped areas had an influence on self-shading in the lower parts of the canopy. It is even possible that removal of seagrass in the fertiliser treatments (which had a major cover of epiphytes) could have increased available light reaching the lower parts of the canopy and that this could actually have aided seagrass growth (and survival) in the short-term. However, a counter argument to this is that cropped areas of seagrass that were attempting to regrow were actually drawing on energy reserves of adjacent seagrass ramets, thereby exacerbating the negative effects of epiphytes.

Whilst we acknowledge that cropping may have influenced seagrass ramets immediately adjacent to a harvested quadrat area, we do not believe that there was a great deal of physiological interconnectedness across our entire plots because: (1) it is apparent that the translocation of underground resources between ramets in seagrasses generally occurs on scales of only a few tens of cm (Marbà et al. 2002), while the plots we sampled from were relatively large at $150 \mathrm{~cm}$ in width, (2) if resources were being 
moved underground on a larger scale (hundreds $\mathrm{cm}$ ) then we may have expected seagrass ramets outside the fertiliser plots to have aided seagrass ramets inside the plots (the zone of influence of the fertiliser on epiphytes was visibly discrete and restricted to the area of the plots, yet seagrass inside the plots declined markedly while seagrass just outside the plots remained apparently healthy), (3) there was little evidence of recovery in fertiliser plots despite the affected plots (which in the case of Amphibolis antarctica were highly visible as bare patches at $27 \mathrm{mo}$ ) being surrounded by apparently healthy seagrass which potentially could have supplied resources, and (4) previous underground excavation of Amphibolis and Posidonia indicates that there is actually a matrix of many 'plants' that collectively form a meadow and it is not simply 1 large clonal organism (S. Bryars pers. obs., see also Cambridge 1999). In summary, we believe that our sampled quadrats were independent and that cropping was a potential (but minor) confounding factor to our observed seagrass response to nutrient exposure.

Nonetheless, in order to counter the possible confounding factors discussed above, future experiments could benefit from (1) removing a smaller amount of seagrass material at each harvest, (2) increasing the size of plots so as to increase the degree of independence of quadrats within a plot, (3) conducting some measurements in situ (such as leaf and stem density), and (4) increasing the total number of plots so as to negate the need to repeatedly sample over time from within the same plot. Nonetheless, each of these options has its own logistical issues.

\section{A possible mechanism of seagrass loss}

It was clear that both epiphyte load and composition changed dramatically with nutrient exposure. Increased epiphyte loads or certain types of epiphytes can potentially reduce the amount of light reaching the surface of seagrass leaves. Some of the epiphytes that proliferated in our fertiliser plots were fleshy brown and green algae (e.g. Colpomenia, Ulva) with large surface areas (we did identify some of the larger algal species but did not quantify algae beyond the 4 broad groups - future work would benefit from more detailed taxonomic discrimination, e.g. Cambridge et al. 2007). Indeed, Posidonia sinuosa showed a decline in seagrass biomass that was consistent with a pattern due to excessive shading: declines commenced with a reduction in leaf density, followed by a reduction in canopy height, which are both typical responses of
Posidonia spp. to chronic reductions in light (Neverauskas 1988a, Gordon et al. 1994, Fitzpatrick \& Kirkman 1995); although responses can be variable (Collier et al. 2009). In Amphibolis antarctica, biomass declines were characterised by reduced stem density and canopy height, and a reduction in the number of leaves per cluster. Each of these responses has been observed to varying degrees in shading trials on $\mathrm{Am}$ phibolis spp. (Mackey et al. 2007, Bryars et al. 2008, Lavery et al. 2009). While shading trials on Posidonia spp. and Amphibolis spp. can result in reduced leaf growth or initiation rates (Gordon et al. 1994, Fitzpatrick \& Kirkman 1995, Mackey et al. 2007, Bryars et al. 2008), leaf growth or initiation rates were maintained in our fertiliser treatments that were displaying increased epiphyte loads. It appears that growth under these conditions could be maintained because the lower parts of the leaves in $P$. sinuosa, and the apical leaves in A. antarctica, were new and therefore relatively free of epiphytes (see below). While some other studies (e.g. Wear et al. 1999) have demonstrated faster growth rates in fertilised seagrasses, they have not observed parallel seagrass declines like we have.

While not quantified here, it was clear that Amphibolis antarctica in the fertiliser treatment had large amounts of epiphytes on both the stems and leaf clusters, while epiphytes in the control treatment tended to be mainly on the stems, particularly the coralline algae. Epiphytes on the leaf clusters in the fertiliser treatment were most prevalent towards the base of the clusters. However, in many cases, epiphytes that had initiated from the stems were also attached to the leaf clusters (which was the main reason why leaf and stem epiphyte loads could not be separated during processing or for analyses). While also not quantified, it was clear that epiphyte loads were higher on the mid and upper sections of Posidonia sinuosa leaves, particularly so in the fertiliser treatment. The lower sections of leaves were relatively free of epiphytes in both treatments.

It is possible that the increased or changed covering of epiphytes on the mid and upper sections of Posidonia sinuosa leaves and the basal leaves in Amphibolis antarctica leaf clusters led to increased necrosis and sloughing of this seagrass material. For $P$. sinuosa, in which seagrass density declined in the fertiliser treatment, the rate of epiphyte-mediated sloughing of old leaves was apparently faster than the rate of new leaf production. Furthermore, leaves gradually became shorter in the fertiliser treatment, suggesting that the rate of epiphyte-mediated sloughing of old leaf material was increased. For A. antarctica, in which leaf clusters became smaller 
in the fertiliser treatment, the rate of epiphyte-mediated old leaf sloughing was apparently also faster than the rate of new leaf production. As leaf initiation rates were similar between control and fertiliser treatments during winter and summer, the lower number of leaves per cluster in the fertiliser treatment must have been due to a greater rate of basal leaf loss.

It was apparent that 15 mo after the final nutrient replenishment (and a recovery period of $12 \mathrm{mo}$ ), the fertiliser-treated Amphibolis antarctica and Posidonia sinuosa had not 'recovered', i.e. seagrass biomass, density and canopy height in the fertiliser treatments were all still significantly lower than in the control treatments. Our result is not surprising given that recovery in Amphibolis and Posidonia following a major disturbance is typically in the order of months to years (Mackey et al. 2007, Collier et al. 2009), with the rate of recovery apparently being dependant on the degree of disturbance (e.g. Collier et al. 2009). Indeed, if the ramets are killed then recovery of denuded areas from external rhizome spreading or propagule settlement may take many years to decades (e.g. Meehan \& West 2000, Bryars \& Neverauskas 2004).

\section{Exceptions to the rule}

Responses of seagrasses and epiphytes to elevated nutrients are highly variable and the addition of nutrients does not always result in algal overgrowth; grazers may also play an important role (Hauxwell \& Valiela 2004, Hughes et al. 2004, Baggett et al. 2010). The response of seagrasses and epiphytes to elevated nutrients may also be influenced by local hydrodynamics (Neverauskas 1988b) and can even vary according to the source population of the seagrass (Hays 2005). Nonetheless, it is apparent from our experimental work, that under certain conditions, if the balance is tipped in favour of epiphytes or certain types of epiphytes, then Amphibolis antarctica and Posidonia sinuosa may slowly decline. Even so, such a response appears to be very site-specific, with a delicate balance between epiphyte load or composition and seagrass survival. For example, in some other South Australian localities that are unaffected by anthropogenic nutrient sources, Posidonia spp. and Amphibolis spp. can have naturally high epiphyte loads (S. Bryars unpubl. data, Bryars 2009). In these situations, there may be natural seasonal declines in epiphyte biomass (as occurred in the controls at our field site, Fig. 3) or seasonal changes in epiphyte composition (e.g. Prado et al. 2008a) that enable the seagrass to survive or, if the high epiphyte loads are seasonally persistent, the seagrass must have adapted to the natural local conditions (e.g. Bryars 2009).

Importantly, the detrimental effect on seagrasses that we observed was achieved with only a minor increase in nutrients, and at a location that was considered to be oligotrophic and free from anthropogenic nutrient inputs. Similarly, Russell et al. (2005) demonstrated an increase in epiphyte load on the macroalga Ecklonia radiata with only a minor increase in dissolved nutrients (nitrate) in an oligotrophic environment, also in southern Australia. Moore \& Wetzel (2000) suggest that the response of seagrasses and epiphytes to increased nutrients may be quite different in oligotrophic versus more enriched environments, where light may play a greater role.

\section{CONCLUSIONS}

Our results have demonstrated that under certain circumstances chronic, yet minor ( 2 to $5 \times$ ), increases in water column nutrients $(\mathrm{N}, \mathrm{P})$ can cause the slow decline of Amphibolis antarctica and Posidonia sinuosa. Furthermore, we found a strong link between changes in epiphyte load or composition and seagrass decline. While we believe that epiphytes caused the reductions in seagrass biomass, the precise mechanism is unclear. Importantly, our experimental observations are consistent with correlative field observations of historical declines of Amphibolis spp. and Posidonia spp. in many locations across southern Australia where nutrient-mediated changes in epiphytes have been attributed as the cause (for reviews see Shepherd et al. 1989, Walker \& McComb 1992). Thus, future management decisions regarding the anthropogenic discharge of nutrients into shallow, sheltered, oligotrophic systems that are dominated by Amphibolis spp. or Posidonia spp. should be undertaken with extreme caution. Nonetheless, predicting when and where the anthropogenic discharge of nutrients will negatively impact on seagrasses remains problematic, and coastal managers need to assess each situation on a case-by-case basis.

Acknowledgements. This work was part of the Adelaide Coastal Waters Study (ACWS). We acknowledge the financial and other support provided by the ACWS Steering Committee including the South Australian Environment Protection Authority, SA Water Corporation, the Torrens Patawalonga and Onkaparinga Catchment Water Management Boards, Department for Transport Energy and Infra- 
structure, Mobil Refining Australia Pty, TRU energy, Coast Protection Board and PIRSA. Non-funding ACWS Steering Committee members include the Conservation Council of SA, SA Fishing Industry Council, Local Government Association, Department of Water Land and Biodiversity Conservation and Planning SA. We acknowledge the intellectual input from the ACWS Technical Review Committee. We thank E. O'Loughlin, J. Lill, G. Mount, G. Westphalen, M. Fernandes, S. Nayar, B. Miller-Smith, Y. Eglinton, D. Gonzalez and M. Barrett for assistance with field and laboratory work. Thanks to T. Laperousaz for identifying the gastropods. Thanks also to A. Cheshire for guidance and input in the early stages of the study and to S. Seddon who was instrumental in the development of the research proposal. We thank P. Fairweather and B. Gillanders for guidance and intellectual input. Thanks also to J. Tanner, D. Turner and J. Nicol for comments on an early draft of the manuscript. Seagrass was collected under a general exemption held by SARDI Aquatic Sciences. The manuscript was improved greatly by comments made by 4 anonymous MEPS reviewers and the Responsible Editor from MEPS.

\section{LITERATURE CITED}

Baggett LP, Heck KL Jr, Frankovich TA, Armitage AR, Fourqurean JW (2010) Nutrient enrichment, grazer identity, and their effects on epiphytic algal assemblages: field experiments in subtropical turtlegrass Thalassia testudinum meadows. Mar Ecol Prog Ser 406:33-45

Borowitzka MA, Lethbridge RC (1989) Seagrass epiphytes. In: Larkum AWD, McComb AJ, Shepherd SA (eds) Biology of seagrasses: a treatise on the biology of seagrasses with special reference to the Australian region. Elsevier Science Publishing Company, New York, NY, p 304-345

Borowitzka MA, Lavery PS, van Keulen M (2006) Epiphytes of seagrasses. In: Larkum AWD, Orth RJ, Duarte CM (eds) Seagrasses: biology, ecology and conservation. Springer, Dordrecht, p 441-461

Bryars S (2009) Can regional nutrient status be used to predict plant biomass, canopy structure, and epiphyte biomass in the temperate seagrass Amphibolis antarctica? Mar Freshw Res 60:1054-1067

Bryars S, Neverauskas V (2004) Natural recolonisation of seagrasses at a disused sewage sludge outfall. Aquat Bot 80:283-289

Bryars S, Collings G, Theil M (2008) Effects of in situ light deprivation on the biomass and epiphyte load of Amphibolis antarctica. In: Bryars S (ed) Restoration of coastal seagrass ecosystems: Amphibolis antarctica in Gulf St Vincent, South Australia. South Australian Research and Development Institute (Aquatic Sciences), Adelaide, Publication No. F2008/000078-1, p 54-61

Burkholder JM, Mason KM, Glasgow HB (1992) Water column nitrate enrichment promotes decline of eelgrass Zostera marina: Evidence from seasonal mesocosm experiments. Mar Ecol Prog Ser 81:163-178

Burkholder JM, Tomasko DA, Touchette BW (2007) Seagrasses and eutrophication. J Exp Mar Biol Ecol 350: $46-72$

Cambridge ML (1999) Growth strategies of Rottnest Island seagrasses. In: Walker DI, Wells FE (eds) The seagrass flora and fauna of Rottnest Island. Western Australia, Western Australian Museum, Perth, p 1-24

Cambridge ML, Chiffings AW, Brittan C, Moore L, McComb
AJ (1986) The loss of seagrass in Cockburn Sound, Western Australia. II. Possible causes of seagrass decline. Aquat Bot 24:269-285

Cambridge ML, How JR, Lavery PS, Vanderklift MA (2007) Retrospective analysis of epiphyte assemblages in relation to seagrass loss in a eutrophic coastal embayment. Mar Ecol Prog Ser 346:97-107

Collier CJ, Lavery PS, Ralph PJ, Masini RJ (2009) Shadeinduced response and recovery of the seagrass Posidonia sinuosa. J Exp Mar Biol Ecol 370:89-103

Edgar GJ (1997) Australian marine life: the plants and animals of temperate waters. Reed Books, Victoria

Fitzpatrick J, Kirkman H (1995) Effects of prolonged shading stress on growth and survival of seagrass Posidonia australis in Jervis Bay, New South Wales, Australia. Mar Ecol Prog Ser 127:279-289

> Goecker ME, Heck KL Jr, Valentine JF (2005) Effects of nitrogen concentrations in turtlegrass Thalassia testudinum on consumption by the bucktooth parrotfish Sparisoma radians. Mar Ecol Prog Ser 286:239-248

Gordon DM, Grey KA, Chase SC, Simpson CJ (1994) Changes to the structure and productivity of a Posidonia sinuosa meadow during and after imposed shading. Aquat Bot 47:265-275

Hauxwell J, Valiela I (2004) Effects of nutrient loading on shallow seagrass-dominated coastal systems: patterns and processes. In: Nielsen S, Banta G, Pedersen M (eds) Estuarine nutrient cycling: the influence of primary producers. Kluwer Academic Publishers, Dordrecht, p 59-92

Hays CG (2005) Effect of nutrient availability, grazer assemblage and seagrass source population on the interaction between Thalassia testudinum (turtle grass) and its algal epiphytes. J Exp Mar Biol Ecol 314:53-68

> Heck KL Jr, Valentine JF (2007) The primacy of top-down effects in shallow benthic ecosystems. Estuaries Coasts 30:371-381

> Heck KL, Pennock JR, Valentine JF, Coen LD, Sklenar SA (2000) Effects of nutrient enrichment and small predator density on seagrass ecosystems: an experimental assessment. Limnol Oceanogr 45:1041-1057

> Heck KL Jr, Valentine JF, Pennock JR, Chaplin G, Spitzer PM (2006) Effects of nutrient enrichment and grazing on shoalgrass Halodule wrightii and its epiphytes: results of a field experiment. Mar Ecol Prog Ser 326:145-156

Hillman K, Lukatelich RJ, Bastyan G, McComb AJ (1991) Water quality and seagrass biomass, productivity and epiphyte load in Princess Royal Harbour, Oyster Harbour and King George Sound. Technical Series 39, Environmental Protection Authority, Perth

Hughes AR, Bando KJ, Rodriguez LF, Williams SL (2004) Relative effects of grazers and nutrients on seagrasses: a meta-analysis approach. Mar Ecol Prog Ser 282:87-99

Jernakoff P, Nielsen J (1997) The relative importance of amphipod and gastropod grazers in Posidonia sinuosa meadows. Aquat Bot 56:183-202

> Keuskamp D (2004) Limited effects of grazer exclusion on the epiphytes of Posidonia sinuosa in South Australia. Aquat Bot 78:3-14

> Kirkman H, Reid DD (1979) A study of the role of the seagrass Posidonia australis in the carbon budget of an estuary. Aquat Bot 7:173-183

Larkum AWD, West RJ (1990) Stability, depletion and restoration of seagrass beds. Proc Linn Soc NSW 106: $201-212$ 
Lavery PS, McMahon K, Mulligan M, Tennyson A (2009) Interactive effects of timing, intensity and duration of experimental shading on Amphibolis griffithii. Mar Ecol Prog Ser 394:21-33

Mackey P, Collier CJ, Lavery PS (2007) Effects of experimental reduction of light availability on the seagrass Amphibolis griffithii. Mar Ecol Prog Ser 342:117-126

- Marbà N, Hemminga MA, Mateo MA, Duarte CM, Mass EM, Terrados J, Gacia E (2002) Carbon and nitrogen translocation between seagrass ramets. Mar Ecol Prog Ser 226:287-300

Meehan AJ, West RJ (2000) Recovery times for a damaged Posidonia australis bed in south eastern Australia. Aquat Bot 67:161-167

Moore KA, Wetzel RL (2000) Seasonal variations in eelgrass (Zostera marina L.) responses to nutrient enrichment and reduced light availability in experimental ecosystems. J Exp Mar Biol Ecol 244:1-28

Neverauskas VP (1987) Monitoring seagrass beds around a sewage sludge outfall in South Australia. Mar Poll Bull 18:158-164

- Neverauskas VP (1988a) Response of a Posidonia community to prolonged reduction in light. Aquat Bot 31:361-366

Neverauskas VP (1988b) Accumulation of periphyton on artificial substrata near sewage sludge outfalls at Glenelg and Port Adelaide, South Australia. Trans R Soc S Aust 112:175-177

> Prado P, Alcoverro T, Romero J (2008a) Seasonal response of Posidonia oceanica epiphyte assemblages to nutrient increase. Mar Ecol Prog Ser 359:89-98

Prado P, Collier CJ, Lavery PS $(2008 b){ }^{13} \mathrm{C}$ and ${ }^{15} \mathrm{~N}$ translocation within and among shoots in two Posidonia species from Western Australia. Mar Ecol Prog Ser 361:69-82

Ralph PJ, Gademann R, Dennison WC (1998) In situ seagrass photosynthesis using a submersible, pulse-amplitude modulated fluorometer. Mar Biol 132:367-373

Ralph PJ, Tomasko D, Moore K, Seddon S, Macinnis-Ng CMO (2006) Human impacts on seagrasses: eutrophication, sedimentation, and contamination. In: Larkum AWD, Orth RJ, Duarte CM (eds) Seagrasses: biology, ecology and conservation. Springer, Dordrecht, p 567-593

Romero J, Lee KS, Pérez M, Mateo MA, Alcoverro T (2006) Nutrient dynamics in seagrass ecosystems. In: Larkum AWD, Orth RJ, Duarte CM (eds) Seagrasses: biology, ecology and conservation. Springer, Dordrecht, p 227-254

Russell BD, Elsdon TS, Gillanders BM, Connell SD (2005) Nutrients increase epiphyte loads: broad-scale observa-

Editorial responsibility: Kenneth Heck Jr., Dauphin Island, Alabama, USA tions and an experimental assessment. Mar Biol 147: $551-558$

Seddon S, Cheshire AC (2001) Photosynthetic response of Amphibolis antarctica and Posidonia australis to temperature and dessication using chlorophyll fluorescence. Mar Ecol Prog Ser 220:119-130

Shepherd SA, McComb AJ, Bulthuis DA, Neveraukas VP, Steffensen DA, West R (1989) Decline of seagrasses. In: Larkum AWD, McComb AJ, Shepherd SA (eds) Biology of seagrasses: a treatise on the biology of seagrasses with special reference to the Australian region. Elsevier Science Publishing, New York, NY, p 346-388

Short FT, Burdick DM, Kaldy JE III (1995) Mesocosm experiments quantify the effects of eutrophication on eelgrass, Zostera marina. Limnol Oceanogr 40:740-749

Silberstein K, Chiffings AW, McComb AJ (1986) The loss of seagrass in Cockburn Sound, Western Australia. III. The effect of epiphytes on productivity of Posidonia australis Hook. F. Aquat Bot 24:355-371

Valentine JF, Duffy JE (2006) The central role of grazing in seagrass ecology. In: Larkum AWD, Orth RJ, Duarte CM (eds) Seagrasses: biology, ecology and conservation. Springer, Dordrecht, p 463-501

Walker DI (1985) Correlations between salinity and growth of the seagrass Amphibolis antarctica (Labill.) Sonder \& Aschers, in Shark Bay, Western Australia, using a new method for measuring production rate. Aquat Bot 23:13-26

Walker DI, McComb AJ (1992) Seagrass degradation in Australian coastal waters. Mar Pollut Bull 25:191-195

Walker DI, Kendrick GA, McComb AJ (2006) Decline and recovery of seagrass ecosystems - the dynamics of change. In: Larkum AWD, Orth RJ, Duarte CM (eds) Seagrasses: biology, ecology and conservation. Springer, Dordrecht, p 551-565

> Waycott M, Duarte CM, Carruthers TJB, Orth RJ, and others (2009) Accelerating loss of seagrasses across the globe threatens coastal ecosystems. Proc Natl Acad Sci USA 106:12377-12381

Wear DJ, Sullivan MJ, Moore AD, Millie DF (1999) Effects of water-column enrichment on the production dynamics of three seagrass species and their epiphytic algae. Mar Ecol Prog Ser 179:201-213

Wilson B (1993) Australian marine shells: prosobranch gastropods. Part 1. Odyssey Publishing, Kallaroo

> Wressnig A, Booth DJ (2008) Patterns of seagrass biomass removal by two temperate Australian fishes (Monacanthidae). Mar Freshw Res 59:408-417

Submitted: January 14, 2010; Accepted: September 3, 2011 Proofs received from author(s): October 31, 2011 